\section{Earthquake in Rumania}

EARLY on the morning of November 10, a very intense earthquake shook nearly all Rumania, and was also felt in Sofia, Belgrade, and many other plac ss in the Balkan States. It will be recalled that a strong double earthquake was felt for about 30 seconds in Bucharest on October 22 (see Nature, Nov. 9, p. 615), and that this was at the time thought to be the precursor of a stronger shock. Evidently the supposition was correct, though the time interval between the premonitory shock and the now much stronger one was greater than anticipated.

Although small earthquakes and tremors are by no means unknown in Rumania, that country has in the past not been so severely hit by these catastrophes as other Balkan States such as Greece. The shock of October 22 may have had its epicentre near Barlag, though some damage was done in Bucharest, the capital. The present shock again severely affected the capital, where many famous buildings are reported damaged and destroyed, and where the casualties are probably high. From other towns, including some in the region of the oil wells, damage and casualties are also reported. A further earthquake, said to have caused enormous damage and many casualtios, included among whom w re rescue parties working amid the debris of the first earthquake, occurred early on November 11.

\section{Youth Service Corps}

IN a circular to local authorities (H.M. Stationery Office, 2d.) the Board of Education sets out a new scheme for the physical training of youth between the ages of fourteen and twenty. The ultimate aim is not the creation of a new movement but the co-ordination of already organized local units, the resulting corps to be run by the young people themselves. Arrangements have been made with the War Office for the gradual release, so far as military requirements allow, of experienced leaders, organizers and certain physical training instructors. All available premises, such as gymnasia, halls, playing-fields, sports grounds and swimming-baths, will be utilized. The supply of suitable clothing is also considered. Suggestions concerning methods of appealing to the youth of the country are also given; these include appeals to those leaving school, old scholars' associations, evening institutes, youth rallies, the "Fitness for Service" scheme, contact with industrial workers, and general publicity. A badge scheme is also outlined.

\section{The Suez Canal}

NATURE seventy-one years ago $(1,81 ; 1869)$ recorded the opening of the Suez Canal "in presence of emperors, kings, princes, and potentates; of eminent engineers, famous warriors, and distinguished savants invited from the East and from the West". The question of the canal has, however, dated back to a much earlier period. Tradition has it that Alexander first discussed its feasibility, but decided against it on account of the difficulty of the mouth of the canal becoming silted up. After other projects, the first Napoleon revived the idea, and from that time the question of a ship canal became a standing topic. With progress in the sciences, especially those of immediate bearing such as geology and engineering, the possibility became more and more convincing, and culminated in the opening on November 17, 1869, the result of one of the greatest of modern engineering feats. It may be well to think of the difficulties faced by science at the time, which in the "pre-scientific age rendered man's contests against the works of the winds and sea perfectly hopeless" but with the aid of science were now conquered.

\section{Greece}

THE Greek Mathematical Society has sent an appeal for help and sympathy to the whole brotherhood of mathematicians, in the name of "the birthplace of mathematics, the country of Pythagoras, Plato, Euclid, Archimedes and Apollonius". Not only the mathematician, but also every scholar and scientific man should answer to the call. Of those five great men it so happens that one was born in Sidon and another in Damascus, another in Perga, and the greatest of all in Sicily; nevertheless Greece has a right to claim and speak for them all. In her golden age they contributed to her glory, and her language has preserved their teaching for the world. Greece herself has had five distracted centuries since Byzantium fell, and her fugitive scholars brought the Renaissance into Europe. Even the last hundred years, since Byron and his Philhellenes fought for her independence, have been hard and troubled times. But in the last few years order has reigned, and much has been done. The University of Athens has quickly become a flourishing institution. Her laboratories are busy, her own library and other lesser libraries are rich, the museums there and elsewhere are well kept and beautiful. We may think not only of what she did two thousand years ago, but also honestly admire her part in the art and science and letters of to-day. Great Britain is again on Greece's side, and the readers of NATuRE not least of all.

\section{The Next Total Solar Eclipse}

WITH the October 1 total eclipse of the sun now past (see p. 642 of this issue), and observations in South America at least ruined by clouds, some astronomers will now be looking forward to their next chance. This will come on September 21, 1941. Plans are uncertain at present, because the best place from which to see it will be on the coast of China, between Foochow and Wenchow, as well as farther inland, at Hankow and Nanchang. Whether certain foreign astronomers will be able to set up their instruments there by next September is perhaps rather questionable. The tip of the moon's shadow next September 21 will first touch earth at sunrise in Russia near Astrakhan. Then it will cross the Caspian Sea, the Aral Sea, Turkestan, Tibet and China. After that it will pass across the western Pacific Ocean, including the American island of Guam. Here the sun will be blacked out for about two and a half minutes, or fifcy seconds less than in China, but this would still give time for many valuable observations. 